\title{
Morphology of the digestive system of Lamproglena clariae Fryer, 1956 (Crustacea: Copepoda), a gill parasite of African catfish Clarias gariepinus (Burchell, 1822)
}

\author{
Januscha Moll ${ }^{1}$, Annemariè Avenant-Oldewage ${ }^{2}$
}

${ }^{1,2}$ Department of Zoology, University of Johannesburg, P.O. Box 524, Auckland Park, 2006, Johannesburg, South Africa.E-mails: 'januscha2205@gmail.com²aoldewage@uj.ac.za

ABSTRACT: Lamproglena clariae has a tube-like digestive system, which consists of a foregut, an extensive midgut and a very short hindgut. The oesophagus is connected to the midgut via a funnel-like structure. The midgut can be divided into three zones equipped for digestion and absorption and haemolysed blood occurred in the digestive tract, confirming that $L$. clariae feeds on the host fish's blood. A peritrophic membrane and faecal pellet formation was reported for the first time in this genus.

How to cite this article: Moll J., Avenant-Oldewage A. 2017. Morphology of the digestive system of Lamproglena clariae Fryer, 1956 (Crustacea: Copepoda) a gill parasite of African catfish Clarias gariepinus (Burchell, 1822) // Invert. Zool. Vol.14. No.1. P.45-52. doi: 10.15298/invertzool.14.1.07

KEY WORDS: African catfish, Clarias gariepinus, Copepoda, Lernaeidae, fish parasite, peritrophic membrane.

\section{Морфология пищеварительной системы Lamproglena clariae Fryer, 1956 (Crustacea: Copepoda) - паразита жабр африканского сома Clarias gariepinus (Burchell, 1822)}

\begin{abstract}
Януша Молл', Аннамария Авенант-Олдевэйдж²
1,2 Department of Zoology, University of Johannesburg, P.O. Box 524, Auckland Park, 2006, Johannesburg,South Africa.E-mails: ${ }^{1}$ januscha2205@gmail.com²aoldewage@uj.ac.za

РЕЗЮМЕ: Трубчатый пищеварительный тракт Lamproglena clariae подразделен на переднюю, очень протяженную среднюю и короткую заднюю кишку. между пищеводом и средней кишкой располагается воронкообразная часть пищеварительного тракта. Средняя кишка подразделена на три зоны, специализирующиеся на переваривании пищи, абсорбсции питательных веществ и гемолизе кровию Наличие крови в пищеварительном тракте подтверждает тот факт, что L. clariae питается кровью своего хозяина. Наличие перитрофической мембраны и формирование фекальных шнуров впервые описано для представителей рода Lamproglena.

Как цитировать эту статью: Moll J., Avenant-Oldewage A. 2017. Morphology of the digestive system of Lamproglena clariae Fryer, 1956 (Crustacea: Copepoda) a gill parasite of African catfish Clarias gariepinus (Burchell, 1822) // Invert. Zool. Vol.14. No.1. P.4552. doi: 10.15298/invertzool.14.1.07
\end{abstract}

КЛЮЧЕВЫЕ СЛОВА: африканский сом, Clarias gariepinus, Copepoda, Lernaeidae, паразиты рыб, перитрофическая мембрана. 


\section{Introduction}

The crustacean digestive system is composed of a foregut, midgut with accompanying caeca, glands as well as diverticula and terminates in a hindgut (Dall, Moriarty, 1983). Information on the structure of the alimentary canal of Lernaeidae (Copepoda) is limited to a single manuscript that described the Lernaea cyprinacea L., 1758 digestive system (Sabatini et al., 1987). Therefore, a need exists for detailed information on the digestive systems of other parasitic copepods.

The feeding behaviour of Lamproglena clariae Fryer, 1956 has been described (Marx, Avenant-Oldewage, 1996). The maxillipeds are used as attachment as well as feeding appendages and penetrates the gill tissue and presumably consumes blood and cause severe tissue proliferation and inflammation surrounded the attachment site (Tsotetsi et al., 2005).

Both L. clariae and L. barbicola LeighSharpe, 1930 undoubtedly feed on blood (Fryer, 1968) of which the gut is often full and blood is supplemented in L. clariae by host tissue (Tsotetsi et al., 2005). Whilst feeding, the head of the parasite becomes embedded in proliferated host tissue (Marx, Avenant-Oldewage, 1996). However, the extent of damage varies depending on the species (Fryer, 1968). Already soon after attachment, signs of acute inflammation occur, followed by host tissue proliferation related to attachment and feeding (Tsotetsi et al., 2005) which may interfere with respiration (Sproston et al., 1950). Degradation of blood capillaries occur in Clarias species' gill filaments and heavy infections lead to blood loss resulting from feeding (Sproston et al., 1950). However, in a study on $L$. clariae no correlation between haematocrit values and the intensity of infection occurred, the researchers therefore concluded that moderate infection does not cause anaemia (Tsotetsi et al., 2005).

Presently the function of mouthparts is not fully understood, but feeding presumably involves only two pairs of appendages i.e. the maxillae and maxillipeds (Fryer, 1968).
This paper studies feeding by examining the morphology of the digestive tract using histological sections and mentions feeding appendages following light and scanning electron microscopy. It furthermore reports on gut content for the first time.

\section{Materials and methods}

Lamproglena clariae Fryer, 1956 specimens were collected from Clarias gariepinus (Burchell, 1822) in the Vaal Dam, Deneysville S $26^{\circ} 52.249^{\prime}$, E $28^{\circ} 10.249^{\prime}$, South Africa. Fish were killed by severing the spinal cord and the gills were removed. The samples were fixed in an aceto-formaldehyde alcohol solution and preserved in $70 \%$ ethanol prior to dehydration and embedding in resin. Serial sections were made at $5 \mu \mathrm{m}$ and stained with Heidenhein's azan trichrome stain. Graphic reconstruction according to the method of Pusey (1939) was done and photomicrographs of longitudinal sections and computer software were used to compile a composite image of the digestive tract.

Specimens for scanning electron microscopy were dehydrated in a series of increasing ethanol concentrations. Amyl acetate and liquid carbon dioxide were used to replace ethanol prior to critical point drying. Samples were placed on carbon tape and coated with gold using an Emscope SC 500. Scanning electron micrographs were obtained with a Jeol 5600 scanning electron microscope.

To establish the nature of the food bolus present within the gut, blood from C. gariepinus was collected. The sample was drawn from the dorsal aorta in a vacuum tube and a thin smear was made. The stains were fixed with methanol and stained with Heidenhein's azan. All procedures on animals were approved by the Ethical committee of the University of Johannesburg and meets the South African National Animal Ethics Guidelines.

\section{Results}

Gross morphology. Live specimens showed peristaltic movement of the digestive tract. In 


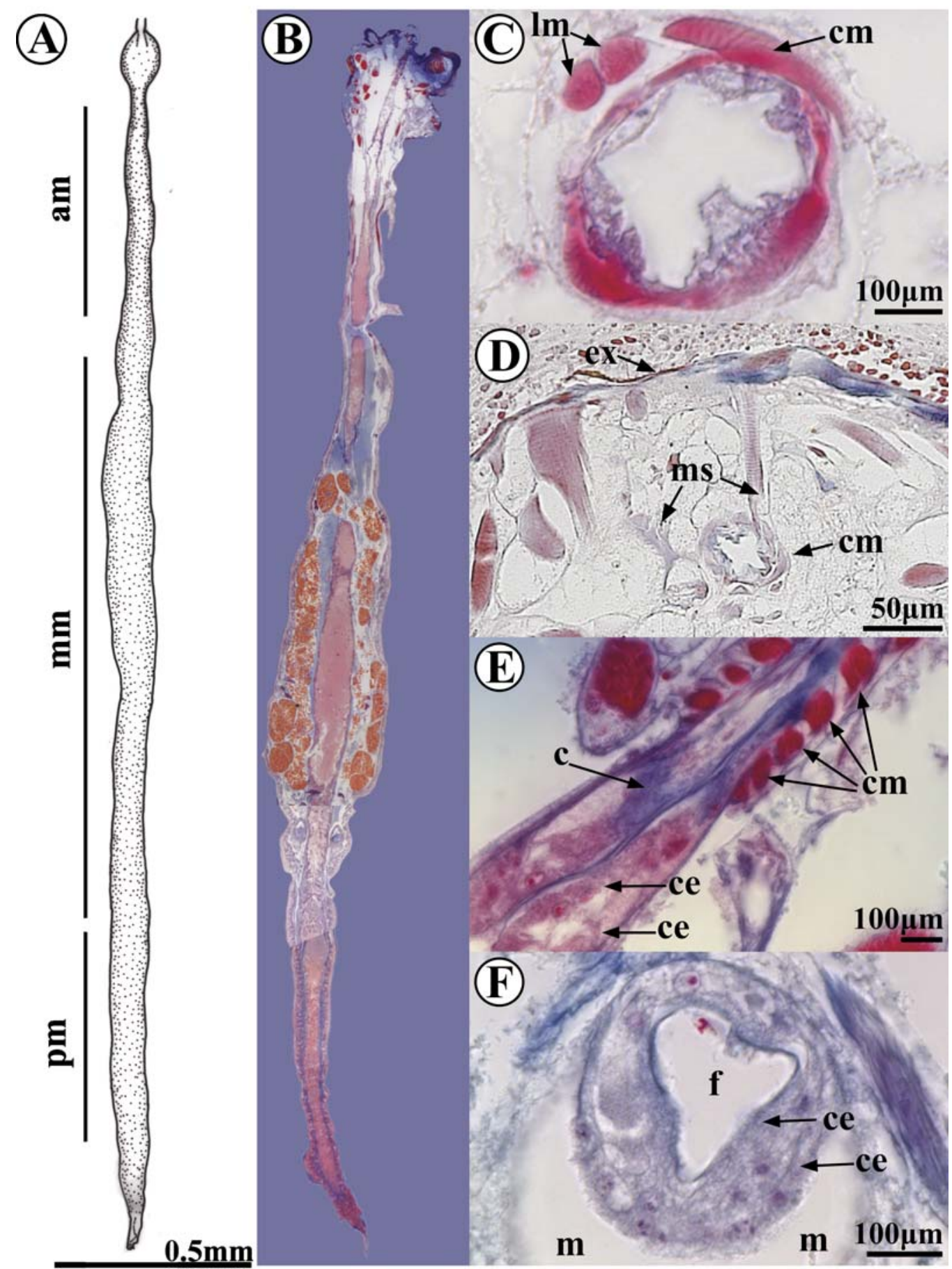

Fig. 1. The digestive system of Lamproglena clariae Fryer, 1956. A - graphic reconstruction, dorsal view. $\mathrm{B}$ - graphic compilation of micrographs of saggital sections through the digestive tract. C - light micrograph of cross section through oesophagus, showing longitudinal as well as circular muscles and cuticular lining. D - light micrograph of cross section through the oesophagus region to show the muscle 
distressed specimens, formation of faecal pellets ceased and intestinal content was released in liquid form.

A graphic reconstruction show that the alimentary canal of L. clariae, is comprised of a foregut terminating in a funnel-like structure, a midgut and hindgut (Fig.1A). A photographic compilation of longitudinal sections confirmed it (Fig. 1B).

Foregut. An anteroventral-situated mouth leads into the foregut. The oesophagus is $3.5 \mu \mathrm{m}$ in length in a $403.80 \mu \mathrm{m}$ specimen $(0.75 \%)$ and surrounded by a well-developed layer of circular muscle as well as a single pair of longitudinal muscles and is lined with cuboidal epithelium which is lined by cuticle (Fig. 1C). The foregut is suspended from the exoskeleton by muscle strands (Fig. 1D) and extends into the midgut via a funnel-like structure (Fig. 1E, F) the funnel consists of two layers of cuboidal epithelial cells both covered by cuticle (Fig. 1E, F). The two cell layers are $4.643 \mu \mathrm{m}$ and $2.289 \mu \mathrm{m}$ thick respectively, measured perpendicular to the basal layer.

Midgut. The midgut is $393.30 \mu \mathrm{m}$ in length in a $403.80 \mu \mathrm{m}$ female specimen that is $97.4 \%$ of the total length. No caeca, glands or diverticula occur and it is not lined by cuticle (Fig 2A). It is tubular and can be divided into three regions based on small differences in cellular composition. The first region (anterior midgut) is situated posterior to the funnel-like structure and characterised by the presence of cuboidal epithelium cells with centrally located, large nuclei and contains small vacuoles. Microvilli occur on some cells.

The second region (median midgut) appears triangular in cross section anteriorly but has a circular shape posteriorly. The region is characterised by vacuolated, club-shaped cuboidal cells, which protrude into the lumen. The nuclei of the cells are large and basally located.
The last region (posterior midgut) is characterised by short, cuboidal cells, with a reduced number and size of vacuoles. Cells are characterised by a centrally located nucleus and numerous vacuoles. These cells bears minuscule microvilli. Concentric rings, surrounding the bolus in the lumen are visible in this part of the midgut, which suggest the formation of a peritrophic membrane (Fig. 2C).

Hindgut. The hindgut is short; $0.030 \mu \mathrm{m}$ in a $403.80 \mu \mathrm{m}$ female specimen $(0.007 \%)$ and is characterised by a cuticle lining. The hindgut is surrounded by a layer of circular muscle and terminates in a dorsally located anus; a round aperture with a diameter of $2.27 \mu \mathrm{m}$.

Gut content. The anterior midgut may contain a food bolus, which consists of damaged cellular material (Fig. 2B). A comparison with host tissue (Fig. 2B insert) confirmed the presence of host blood, albeit in a decomposed state. In the posterior midgut a peritrophic membrane is formed around the food bolus (Fig.2C) and faecal pellets were observed in the hindgut.

External structures. Female L. clariae specimens possess extremely well developed, robust maxillae and maxillipedes (Fig. 2D) these are used for attachment and scraping of host tissue into the buccal caivity.

\section{Discussion}

With a few exceptions, the gut in copepods consist of a tube running virtually the length of the body. The fore- and hindgut, which are derived from the ectoderm, are lined with cuticle and storage, trituration and early digestion take place in the foregut (Dall, Moriarty, 1983). The midgut, derived from endoderm, has cells that are in direct contact with the lumen.

Foregut. According to Ceccaldi (2006) the foregut of Crustacea comprises of a long, straight

strand from which the oesophagus is suspended. E - light micrograph of a longitudinal section through the funnel-like structure showing circular muscles surrounding the oesophagus, a cuticle layer and cuboidal epithelium. F - light micrograph of a cross section through the funnel-like structure at the terminal end of the oesophagus. Two layers of cuboidal epithelial cells present as indicated by arrows.

Abbreviations: am — anterior midgut; c — cuticle; ce — cuboidal epithelium; $\mathrm{cm}$ - circular muscles; ex — exoskeleton; $\mathrm{f}$ - funnel-like structure; $1 \mathrm{~m}$ - longitudinal muscle; $\mathrm{m}$ - midgut; $\mathrm{mm}$ - median midgut; $\mathrm{pm}$ - posterior midgut. 


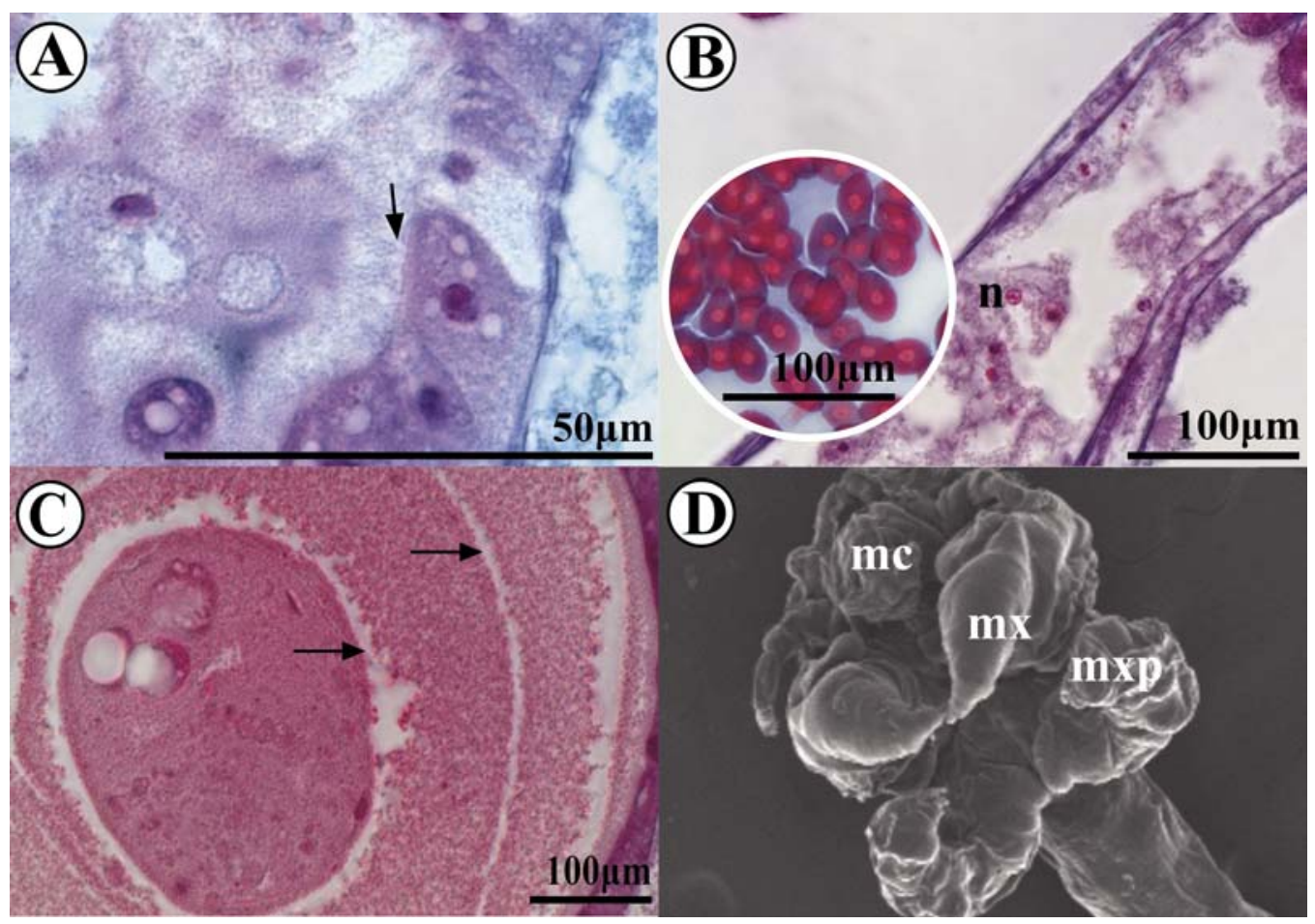

Fig. 2. Micrographs of Lamproglena clariae Fryer, 1956. A — light micrograph of a secretory cell within the digestive tract, minuscule microvilli is present (arrow). The vacuoles within the cell would normally be lipid filled, but the staining method dissolved the lipids. B - light micrograph of a longitudinal section through the foregut, showing a bolus with remains of nuclei and damaged cell, insert showing host blood. $\mathrm{C}$ - light micrograph of histological section through the midgut showing concentric rings (arrows), of a peritrophic membrane. D - scanning electron micrograph showing the mouthparts.

Abbreviations: $\mathrm{mc}$ - mouth cone; $\mathrm{mx}$ - maxillae; $\mathrm{mxp}$ - maxillipede; $\mathrm{n}$ - nucleus.

tube covered by a single layer of cells as confirmed by this study in L. clariae. However, $L$. clariae lacks a valve or partition separating the foregut from the midgut; instead, a funnel-like structure that functions as a partition separator occurs. This structure consists of a double layer of epithelial cells covered by cuticle on both sides and is situated between the fore- and midgut. In copepods, the foregut is well equipped with circular dilator muscles (Dussart, Defaye, 1995). They reported that, especially in carnivorous copepods the mouth and oesophagus are provided with strong muscles that allow ingestion of large prey. In this study, the circular muscles present in the foregut serve as dilatorsconstrictors of the foregut/oesophagus whereas, the longitudinal muscles assist with contraction of the funnel-like structure, which facilitates blockage of the lumen. Furthermore, the muscle strands suspended from the skeleton can aid in dilating the oesophagus.

In both $L$. clariae and $L$. cyprinacea the mouth is part of the foregut which terminates in a funnel-like structure. In L. cyprinacea the structure bears chitinous spurs, which are absent in L. clariae. Sabatini et al. (1987) observed that the funnel-like structure for the first time in Copepoda. They mention that this structure plays a decisive role in the peculiar feeding mechanism of L. cyprinacea. Swimming L. cyprinace $a$ attaches to the host, their maxillae open and the funnel-like portion of the foregut extruded. The structure drags along the chitinous folds of the oral cavity. In L. clariae, mature 
females attach to a host and the head becomes embedded in proliferating host tissue whilst the maxillae and maxillipeds scrape cellular material into the mouth cavity (Tsotetsi et al., 2005). Circular dilator muscles as well as longitudinal muscles were observed around the oesophagus of $L$. clariae and alternating constriction and dilation of these would assist in transport of food material through peristalsis. Combining blockage of the terminal end by the funnel and dilation of the circular muscle, the oesofagus will create negative pressure in the lumen to constitute a very able sucking pump to suck blood.

Midgut. Gross morphology of the copepod midgut is variable; yet it is divided into three major parts (Dussart, Defaye, 1995). Digestion occurs within the first two regions and the posterior region is involved in absorption of nutrients and faecal pellet formation (Dussart, Defaye, 1995). It is the site where most enzyme secretion and absorption takes place and consists of a single cell layer of glandular epithelium in direct contact with blood in the haemocoel, which enables rapid absorption of nutrients (Dall, Moriarty, 1983; Ho, Honma, 1983). This characteristic is also exhibited by $L$. clariae, where limited storage occur within the midgut.

As the midgut serves a dual role of secreting enzymes and absorption, it is expected that the epithelium in this region has differentiated into at least two cell types (Dall, Moriarty, 1983); secretory and mucopolysaccharide-containing types respectively. Microvilli, suggesting absorptive functions, have been described in Copepoda (Raymont et al., 1974) and are present within the midgut of L. clariae. Secretory cells aid in digestion and occur in a mixture of cells distinguished by presence and absence of microvilli. (Arnaud et al., 1980, 1987, 1991). In Lernaeolophus aceratus Ho et Honma, 1983, a pennelid copepod, the epithelium of the oesophagus produces enzyme-filled vesicles that are released into the lumen of the midgut where they burst and the content is released (Ho, Honma, 1983).

Columnar cells as well as amoeboid cells were described in the midgut of Paranthessius anemoniae Claus, 1889 and it was speculated that these cells function in uptake of food material. Furthermore, the columnar epithelium bears a brush border, whereas the amoeboid cells were reported to contain a large central vacuoles and protrude into the lumen (Briggs, 1977), similar to the club-shaped cells of the midgut in L. clariae suggesting absorption also occurs via these cells.

Two types of vacuolar cells occur in the midgut of $L$. cyprinacea and these cells were sorted depending on size and granule distribution. The majority of cells had granules of varying sizes, which were often so abundant that they masked the cytoplasm; the remainder are characterised by either discrete or very large granules. These cells were in the minority and only present in the lateral pouches of the midgut (Sabatini et al., 1987). Similarly, two types of cells were previously described in Ergasilus sieboldi Nordmann, 1832; one granular and the other vacuolate (Einszporn, 1965). No pouches were observed in the midgut of L. clariae and histological sections revealed only two types of vacuolated cells. The cells differed on grounds of the amount of vacuoles they possessed. One type protruded into the lumen and the other was normal cuboidal cells. Some cells only contained a single vacuole, the remainder numerous vacuoles (Sabatini et al., 1987).

The peritrophic membrane in Copepoda forms an envelope around what is to become the faecal pellet (Ceccaldi, 2006). It is secreted by the midgut of copepods such as calanoids, cyclopoids and a harpacticoid respectively (Gould, 1957; Yoshikoshi, Kô, 1988), This report is the first of a peritrophic membrane in Lernaeidae and in any Lamproglena species.

Hindgut. The short copepod hindgut is separated from the midgut by a valve and opens posteriorly or post dorsally via the anus (Boxshall, 1992). In L. clariae, no valve was observed separating the mid- and hindgut from each other. The hindgut in copepods is usually a simple, cuticle lined tube, with the function of defecation (Briggs, 1977). The muscular hindgut pumps water into the gut (Dall, Moriarty, 1983). Anal uptake of water occurs in many 
Crustacea (Fox, 1952; Dall, 1967) aiding in defaecation by acting as an enema (Fox, 1952), however, later researchers found that it could assist in electrolyte removal following observations from numerous hypo-osmoregulatory experiments (Dall, 1967).

Mouthparts. The form and functions of the appendages depend on the specialisations of the copepod group (Ceccaldi, 2006) and Copepoda comprise numerous morphotypes. Comparing L. clariae with $L$. cyprinacea, it was found that the buccal cavity in the latter is delimited by a labrum, mandibles, maxillulae, and a lower lip (Sabatini et al., 1987), the oral opening covered by large maxillae, which terminate in non-motile hooks with secondary motile hooks. The mouth has chitinous folds and possess two rows of triangular teeth. In L. clariae the parasitic females are superbly equipped to attach to the host fishes gills to obtain food utilising their robust mouthparts (Marx, Avenant-Oldewage, 1996; Tsotetsi et al., 2005). The appendages scrape tissue from the host's gill also severing capillaries and this leads to haemorrhage. When circular muscles surrounding the oesophagus dilate, the funnel will be drawn into the lumen of the oesophagus forming a plug and a vacuum is created, promoting the intake of blood cells and cellular material through the slit-like mouth. Thereafter, contraction of the circular muscles and relaxation of the longitudinal muscles will release the funnel plug; it will extend and the content of the foregut will be released into the midgut.

The long midgut aids in absorption; because of the abundant club shaped cells protruding into the lumen, which increases the absorption surface. No valves were found within the alimentary tract. The circular muscles contracts in succession to cause peristaltic movement.

Gut content. Red blood cells decompose after consumption and cell membranes becomes deformed and eventually disappears, resulting in the appearance of haemolysed blood cells and eventually cytoplasm also disappears due to the intestinal enzyme actions (Einszporn, 1965). Haemolysed blood was observed in the intestinum of L. clariae, although blood cell nuclei were distinguished in the anterior midgut. A previous study reported that gill tissue was also consumed (Tsotetsi et al., 2005). Similarly, a clump of blood occurred in the oral cone of $L$. aceratus although they were not able to conclude how the parasite acquire these. Furthermore, erythrocytes were present in the midgut, amongst enzyme vesicles being digested (Ho, Honma, 1983)

\section{Acknowledgements}

We thank the National Research Foundation and University of Johannesburg (UJ) for funding to AAO and UJ for infrastructure, Spectrum the Faculty Analytic Facility for technical support related to scanning electron microscopy, Mrs. Edie Lutsch for support preparing histological sections and Lourelle Neethling for support with photo plate outlay. We thank an anonymous reviewer for very constructive suggestions.

\section{References}

Arnaud J., Brunet M., Mazza J. 1980. Structure et ultrastructure comparées de l'intestin chez plusieurs espèces de Copépods Calanoides (Crustacea) // Zoomorph. Vol.95. P.213-233.

Arnaud J., Brunet M., Mazza J. 1987. Rôle des cellules B de l'intestin moyen chez Centropages typicus (Copepoda, Calanoida) // Repr. Nutr. Dév. Vol.27. No.4. P.817-827.

Arnaud J., Brunet M., Mazza J. 1991. Donnés ultrastructurales démontrant le caractère sélectif de l'endocytose par les cellules intestinales de type B chez Hemidiaptomus ingens (Copepoda, Calanoida) // Comptes rendus des Seances. Academie de Sciences (Paris) Serie 3. Science de la vie. P.469-501.

Boxshall G.A. 1992. Copepoda, Vol. 9. Crustacea // Microscopic Anatomy of Invertebrates. New York: WileyLiss, Inc. P.347-384.

Briggs R.P. 1977. Structural observations on the alimentary canal of Paranthessius anemoniae, a copepod associate of the snakelocks anemone Anemonia sulcate // J. Zool. Vol.182. P.353-368.

Ceccaldi H.J. 2006. The digestive tract: Anatomy, Physiology, and Biochemistry // F.R. Schram, J.C.von Vaupel Klein (eds.). Treatise on Zoology - Anatomy, Taxonomy, Biology. The Crustacea, London: Brill. P.522.

Dall W. 1967. Hypo-osmoregulation in Crustacea // Comp. Biochem. Phys. Vol.21. P.653-678.

Dall W., Moriarty D.J. 1983. Functional aspects of nutrition and digestion // Mantel (ed.). The Biology of 
Crustacea. Vol. 5. New York: Academic Press. P.215261.

Dussart B.H., Defaye D. 1995. Copepoda // H. Dumont (ed). Introduction to the Copepoda. Guides to the Identification of the Micro-invertebrates of the Continental Waters of the World. Netherland: SPB Academic Publishing. P.277.

Einszporn T. 1965. Nutrition of Ergasilus sieboldi Nordmann. I. Histological structure of the alimentary canal // Acta Parasit. Pol. Vol.13. No.37. P.71-79.

Einszporn T. 1965. Nutrition of Ergasilus sieboldi Nordmann. II. The uptake of food and the food material // Acta Parasit. Pol. Vol.13. No.37. P.373-380.

Fox H.M. 1952. Anal and oral intake of water by Crustacea // J. Exp. Biol. Vol.29. P.583-599.

Fryer G. 1968. The parasitic Crustacea of African freshwater fishes; their biology and distribution // J. Zool. Vol.156. P.45-95.

Ho J.-S., Honma Y. 1983. Lernaeolophus aceratus, a new species of copepod parasitic on rainbowfish from the Sea of Japan, with notes on food and feeding // J. Crust. Biol. Vol.3. No.2. P.321-328.

Gould D.T. 1957. A peritrophic membrane in Calanoid copepods // Nature. Vol.179. P.325-326.

Marx H.M., Avenant-Oldewage A. 1996. Redescription of Lamproglena clariae Fryer, 1956 (Copepoda, Lernaeidae) with notes on its occurrence and distribution // Crustaceana. Vol.69. P.509-523.
Pusey K.H. 1939. Methods of reconstruction from microscope sections // J. R. Micr. Soc. Vol.59. P.232-251.

Raymont J.E.G., Krishnaswamy S., Woodhouse M.A., Griffin R.L. 1974. Studies on the fine structure of Copepoda. Observation on Calanus finmaarchicus (Gunnerus) // Proc. R. Soc. Lond. Ser.B. Vol.185. P.409-424.

Sabatini M.A., Marini M., Fratello B., Gelosini C., Mola L., Benedetti I. 1987. The digestive apparatus of the parasitic copepod Lernaea cyprinacea L. during development and in the adults // Acta Embryo. Morph. Exp. n.s. Vol.8. No.2-3. P.389-409.

Sproston N.G., Yin W.Y., Hu T. 1950. The genus Lamproglena (Copepoda Parasitica): The discovery of the life-histories and males of two Chinese species from food fishes, revealing their relationship with Lernaea, and of both to the cyclopoidea // Sinensia, n.s. Vol.1. P.51-54.

Tsotetsi A.M., Avenant-Oldewage A., Mashego S.N. 2005. Aspects of the pathology of Lamproglena clariae (Copepoda: Lernaeidae) on gills of Clarias gariepinus from the Vaal River System, South Africa // Afr. Zool. Vol.40. No.2. P.169-178.

Yoshikoshi K., Kô Y. 1988. Structure and function of the peritrophic membranes of copepods // Nippon Suisan Gakkaishi Vol.54. No.7. P.1077-1082.

Responsible editor E.N. Temereva 